\title{
Development Learning Models of Fish Stock Assessment Technique Subjects based E-Learning at Aquatic Resources Technology Management Program Study at the Jakarta Fisheries High School
}

\author{
Heri Triyono, Diana Nomida Munsir, Suriani
}

\begin{abstract}
The aim of the study in general is to develop a learning model fish stock assessment techniques based e-learning to meet competencies for program Students study of Aquatic Resources Management Technology in the Jakarta Fisheries University. This research uses research and development methods. Result of study: In the field trial, the value obtained from the results of the post-test is higher than the value of the Pre-test, the average value of the results of the pre-test 62 and the post-test average value of 86.79 , so there is an increase of 24,79 points, the rate of increase is very significant, meaning that this figure shows that the model developed can improve student learning achievement in the Study Program of Aquatic Resources Management Technology. While the average percentage value obtained from field trials is $88.88 \%$, this number is higher than the learning objectives specified in the specific instructional objectives of $80 \%$.
\end{abstract}

Index Terms: Learning Model, E-Learning, Fish Stock Assessment Techniques, Jakarta Fisheries University.

\section{INTRODUCTION}

The rapid increase in world population has increased the demand for fish. Increased fishing efforts, both an increase in the number of fishing fleets and uncontrolled fishing technology in most countries in the past have accelerated the decline in fish resource stocks in most of the world's fisheries (Nikijuluw, et all, 2007). This is what encourages Indonesia as one of the richest fisheries resources, lately prioritizing the utilization of the fisheries resources it has.

The condition of the waters in Southeast Asian countries, especially Indonesia has its own uniqueness. This uniqueness is a large area, consisting of islands with sea boundary disputes, dominated by small-scale fishermen with diverse target species, and a large but less leadership nation (lack of established / tested institutions). The international community has begun to propose action plans to maintain the sustainability of fisheries resources in the long term. The regulation of fish resources based on the calculation of the number of fish stocks and several methods of regulating fishing has been carried out. However, these efforts have not

Revised Manuscript Received on April 19, 2019.

Heri Triyono, Posgraduate Educational Technology, Universitas Negeri Jakarta, Jakarta, Indonesia.

Diana Nomida Munsir, Posgraduate Educational Technology, Universitas Negeri Jakarta, Jakarta, Indonesia.

Suriani, Posgraduate Educational Technology, Universitas Negeri Jakarta, Jakarta, Indonesia.. yet shown encouraging progress. In fact, the potential numbers of fish resource stocks that are used as the basis for the management of fish resources are often doubtful and are not often a matter of debate regarding the numbers that are not in accordance with the actual conditions.

Based on the results of observations, college graduates especially those related to marine and fisheries management in Indonesia, seem to have not been able to quickly adapt to the needs of the modern industrial world of fisheries. As a result, the unemployment rate of college graduates from time to time continues to increase. This condition is caused by the perception gap between the management of higher education institutions in producing graduates with industrial managers who will use these college graduates (Gaspersz, 2002). Academic orientation in higher education is not only fixated on the routine of the learning process they have been doing.

Improving the quality of learning can be initiated from the learning design. "Instructional design is a way to plan your training program from the moment you have the idea for it (or the idea is given to you) until the moment you complete your revisions of your first effort and get ready to run the program again. It is a working model that you can use to manage the concepts and tasks that are part of a successful training process" (Piskurich, 2000).

Well-designed learning by paying attention to conditions and choosing the right teaching materials will improve the quality of learning. By itself it will improve student learning outcomes, not only on the cognitive aspects, but also aspects of attitudes and skills. This means that the improvement of learning outcomes must begin with the improvement of the quality of learning design by determining the appropriate learning resources and according to the needs of students. In the global era as it is today, it must relate to technology, especially information technology. This is because the technology has affected our daily lives. Information is already a 'commodity' as is just another economic item.

The role of information is becoming bigger and more real in the modern world as it is today. This is understandable because the community is now heading towards the era of information age or the knowledge society. 
Therefore, it is not surprising that there are universities that offer information or information technology majors, so that the university develops rapidly. One of the learning models offered is an e-learning innovation model. e-Learning is the use of internet technology. e-learning is a form of conventional learning as outlined in digital format through internet technology. Therefore e-Learning can be used in distance education systems as well as conventional education systems. In conventional education e-Learning functions are not to replace, but strengthen conventional learning models.

One of the subjects that must be followed by students of Technology for Management of Aquatic Resources study program is the Fish Stock Estimation Engineering course with a weight of 3 credits. This course is delivered in an odd semester. This course has the scope of the presentation of theories and an understanding of the techniques of estimating fish stocks. Then the material is studied by practicing estimating fish stocks.

\section{METHOD OF RESEARCH}

This research uses research and development $(\mathrm{R} \& \mathrm{D})$ methods. Gall, Gall, and Borg stated that: Research and development is an industry-based development model where research findings are used to design new products and procedures, which are systematically field-tested, evaluated, and refined until all meet the specified criteria namely effectiveness , quality, or similar standards (Gall, Gall, \& Borg, 2007: 589). The research and development model refers to the opinion of Richey \& Nelson (2000).

Development research methodology facilitates a study of new models, tools, and procedures so that we are trusted to anticipate their effectiveness and efficiency. In this way, we can determine the relevance of context-specific findings for other teaching and learning environments and identify new general principles of design, development, and evaluation. This opinion indicates that a development research is an effort to facilitate the development of new models, tools, procedures and strategies so that effective and efficient uses of the products developed are found.

According to Gay, Mills, \& Airasian (2009), "Research and development is the process of examining consumer needs and then developing products to meet those needs. This product is in the form of training materials, study materials, media materials, and management systems. Referring to the definition, this study produces learning material. Whereas Gall et al., (2007: 594), the results of $\mathrm{R} \& \mathrm{D}$ are the contribution of new knowledge and raising new questions, about the effects of problem-based learning on performance skills and perceptions of student self-ability. In other words, $\mathrm{R}$ $\& \mathrm{D}$ is a product development process and produces efficient products for improving student performance.

This study uses research and development that refers to the Gall \& Borg Model, namely the Steps of System Approach Model of Educational Research and Development adopted from the Dick \& Carey Model, namely Systematic Design of Instruction. This research and development method uses preliminary research. Initial research includes gathering information - including literature reviews, class observations, and current conditions.

The data collection method used is a qualitative method consisting of interviews, focus group discussions, observations and field notes. In this study, instruments that are validated and tested are needed first before being used for data explorer. Validation and evaluation can done, for example by interviewing each user or test subject. The procedure for validation and field trials in formative evaluations is carried out for learning development products (Schwier \& Misanchuk, n.d.6060-270), as follows: (1) One to one expert, that must be examined individually by material experts, learning design experts, and learning media experts; (2) One to one learner, namely test try individual done on the subject of learning material users developed; (3) Small groups, which are tested on small groups about conformity to the principles of learning; and (4) Field trial, namely carrying out the test try the field.

\section{RESEARCH RESULT}

\section{A. Preliminary Research}

The process of preliminary research or identification of needs involves three parties that are used as sources of information (informants) to explore instructional needs, namely students (students and graduates), educators (instructors and chairmen of study programs as managers of education) and communities (graduate users). the three informants focused on efforts to find out and provide answers / clarifications regarding:

1. The gap between current competencies and the expected and supposed competencies of students (students) Technology Study Program of STP Aquatic Resources Management;

2. How is the condition and implementation of the Engineering Course course for fish stock estimation that is currently running;

3. Ideal Purpose of Learning Program for Fish Stock Estimation Technique according to respondents' expectations;

4. What about the initial findings, which parts can be used as the basis for the steps in developing learning materials.

From the information provided by students regarding the Fish Stock Estimation Engineering course, there are a number of things to note and considerations include: (1) Not understanding the need to estimate fish stocks, (2) Not understanding fisheries data collection and data collection techniques, (3) Not understanding how to estimate fish growth, (4) Don't understand how to estimate fish mortality, (5) Don't understand how to predict fish stock estimation models associated with multispecies / multi-problem problems, and (6) Don't understand the relationship between stock and recruitment and how to calculate it using a computer software application.

This is reinforced by the learning outcomes of the Fish Stock Estimation Engineering subject for the last five years presented in Table 1. The Academic Achievement Index for the Fish Stock Estimation Engineering course is 2.78, considering that this subject becomes the basis of knowledge for courses in the following semester and fisheries management in Indonesia. 
Table 1. Academic Achievement Index (AAI) in Fish Stock Estimation Engineering Subject at Technology Management Program Aquatic Resources Study Program

\begin{tabular}{|c|c|c|c|}
\hline No & $\begin{array}{c}\text { Semeste } \\
\text { r/Year }\end{array}$ & $\begin{array}{c}\text { Average Academic } \\
\text { Achievement Index (AAI) }\end{array}$ & Category \\
\hline 1 & $5 / 2013$ & 2.70 & Less \\
\hline 2 & $5 / 2014$ & 2.80 & Less \\
\hline 3 & $5 / 2015$ & 2.75 & Enough \\
\hline 4 & $5 / 2016$ & 2.80 & Enough \\
\hline 5 & $5 / 2017$ & 2.85 & Less \\
\hline
\end{tabular}

If examined more specifically, these problems occur because of the background of students from high school (Science and Social Sciences Department), Fisheries High School (SMK) and Middle Fisheries Public School (MFPS). Learning activities related to fisheries are relatively rare and even none except for students who come from graduates of Fisheries Vocational School and MFPS, and even then relatively few. Achievements that have not described the desired AAI are also caused by other factors discussed in the previous section. It is expected that by using a new learning design, AAI will be obtained more than 3.5. The achievement of these targets is quite realistic so that it is necessary to improve the design of the learning both in terms of non-printed learning materials, teaching guidelines, and study guides. Another important step is to design a fun learning strategy and apply it in the classroom. This is necessary, because students are assumed to only be able to learn and absorb learning if the learning process is fun. Furthermore, the results of the implementation of learning are then evaluated and convey the results to students. This is useful for developing learning motivation for students. Noting the results of the initial research described above, it can be seen clearly that the problem of learning processes that are less attractive and less communicative is the cause of poor student achievement in the Study Program of Aquatic Resources Management Technology of Jakarta Fisheries University, so that the expected competencies cannot be achieved. In order for the competencies expected to be achieved, it is necessary to determine the ideal general learning objectives based on respondents' expectations combined with the learning objectives of the Fish Stock Assessment Engineering subject.

After conducting preliminary research or identifying needs, the general learning objectives or general instructional objectives of the Fish Stock Assessment Subject are "After Following the Technical Course in Fish Stock Assessment, Semester 5 Students of Aquatic Resources Management Technology will have the ability to implement concepts and procedures relating to qualitative and quantitative fish stock estimates. Conduct learning analysis To achieve the general learning objectives that have been arranged above, it is necessary to prepare a learning analysis, the activities carried out in the learning analysis are identifying a list of sub-competencies and arranging relationships between sub-competencies with other sub-competencies leading to general competence. By conducting a learning analysis will be drawn the arrangement of sub-competencies from the beginning to the very end. The number and arrangement of the sub-competencies will give the teacher confidence that the general competencies that are printed on the general learning objectives can be achieved effectively and efficiently.
Analysis of this learning is made in the form of pictures or schemes to make it easier to observe the analysis of learning, in this learning analysis consists of fourteen competencies to be taken in one semester so that they will be able to achieve the general learning objectives that have been set.

\section{B. Results of Model Feasibility}

The results of the feasibility of the model are the results of formative evaluation. The results of the formative evaluation are outlined in the explanation below:

\section{Evaluate experts}

\section{a. evaluation of learning design experts}

One-to-one expert design This learning is carried out by experts in the field of Educational Technology and Education Science Doctors who are competent as Learning Design experts. The results of the design expert's evaluation of the learning material Engineering Subject Fish Stock Estimation gave an average rating of $90.38 \%$ meaning that the model developed was categorized as very feasible and very good, then the learning design expert gave the following suggestions and inputs:

1) For printed learning materials it is recommended to use paper sizes such as the size of a book, such as those used by some book publishers.

2) The material presented so that it is easy to understand, then each material presented from each chapter is equipped and supported by enriching learning resources that can be accessed using the website page through a copy of the URL and QR Code.

The results of expert validation presented based on indicators can be seen in Graph 1:

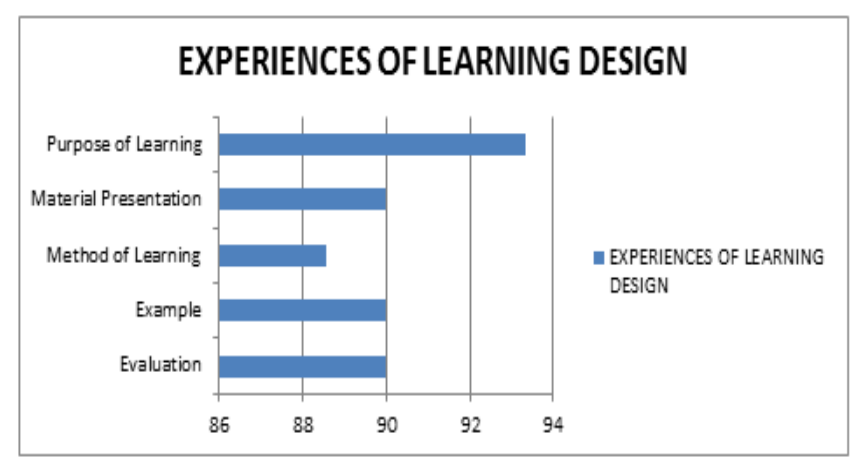

Graph 1. Results of Learning Design Expert Validation

\section{b. Learning Media Expert Evaluation}

Expert Evaluation (one-to-one expert) this media is carried out by learning media experts. From the results of the Media expert's evaluation of the learning materials in the Engineering Stock of Fish Stock Estimation, an average rating of $93.56 \%$ was given, this figure shows that the learning material products are very feasible and very good for use in the learning process.

The results of the validation by instructional media experts on the draft material for learning are outlined in Graph 2: 


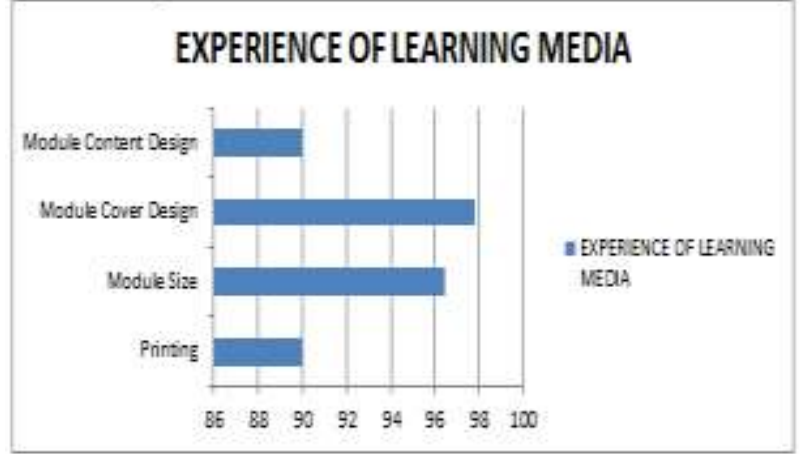

Graph 2. Results of Learning Media Expert Validation

\section{c. Content / Material / Content Evaluation}

Content / Material Evaluation / content is carried out by experts who are experts in the Fish Stock Estimation Technique, Lecturers who are in charge of Engineering Stock Prediction of Fish Stock, experts in applying technology in education and mastering languages. From the results of the evaluation of material experts (content) on the learning materials of Engineering Stock Prediction Fish Stock was given an average rating of $91.44 \%$, meaning that the material experts gave an assessment of the products of this development which is very feasible and very good to be used in the learning process (Graph 3). Of the three validations carried out by learning design experts, learning media experts, and material experts, are the basis for conducting individual trials and followed by small group testing and field trials.

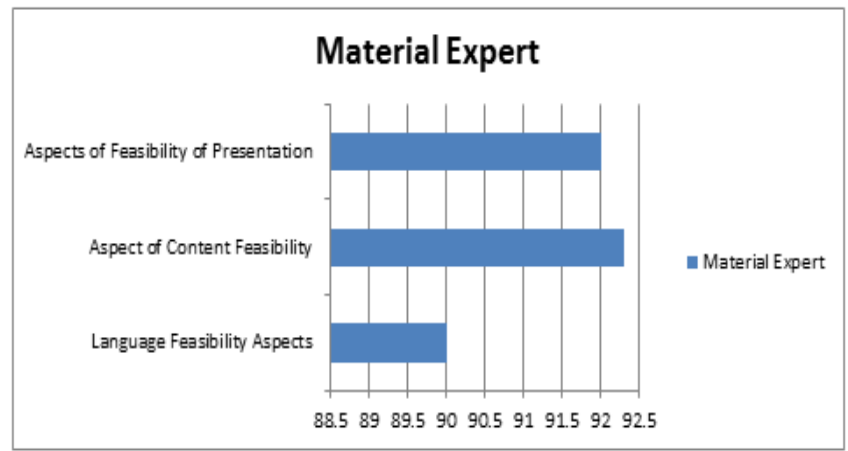

Graph 3. Results of Material Expert Validation

The results of the validation of the three experts above can be stated in the form of Graph 4.

Based on Graph 4 which is the result of validation by the three experts, it shows that the expert team recommends continuing on individual trials. The percentage of validation results from the expert team are in the very feasible category. Thus it can be concluded that the draft development of the Fish Stock Estimation Engineering learning model developed has followed the procedures and rules for the development of learning materials so that it can be continued at the next trial stage.

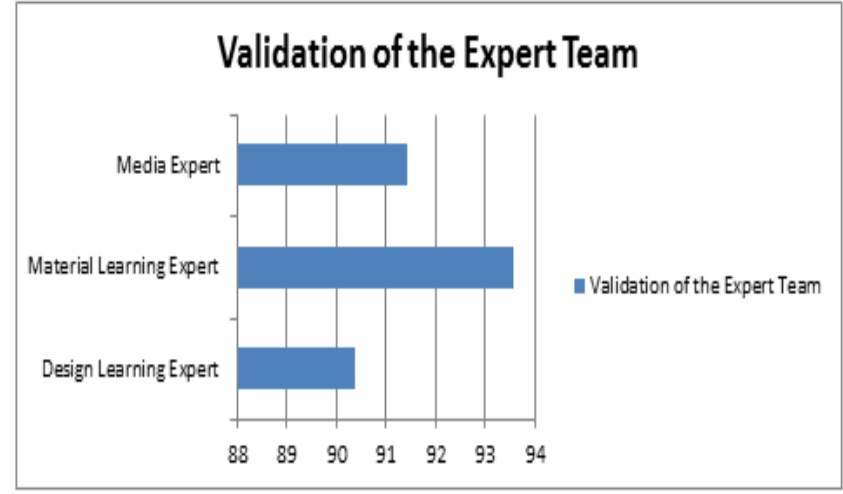

Graph 4. Results of the Expert Team Validation on the draft development

\section{Individual testing}

In the individual evaluation (one-to-one learner) stage this is done by involving three students individually. The three students selected have the characteristics according to the target. The researcher appointed three students who had low, moderate, and high abilities. In this trial students are introduced to learning materials for the Fish Stock Estimation Engineering subject.

Based on this trial, the student responses are shown in Graph 5. Based on the picture, the response of the trial to the quality of the learning material was illustrated at the average achievement level of 3.97 (79.33\%). This value is in the good category. Based on these achievements, it can be seen that aspects of learning design, aspects of language feasibility, aspects of graphics (cover design and design content of learning materials) and aspects of benefits, have clearly been captured by the subject. The steps for using learning materials have been arranged coherently and systematically. The conclusion that can be drawn from the results of this trial is that the product developed is feasible to use.

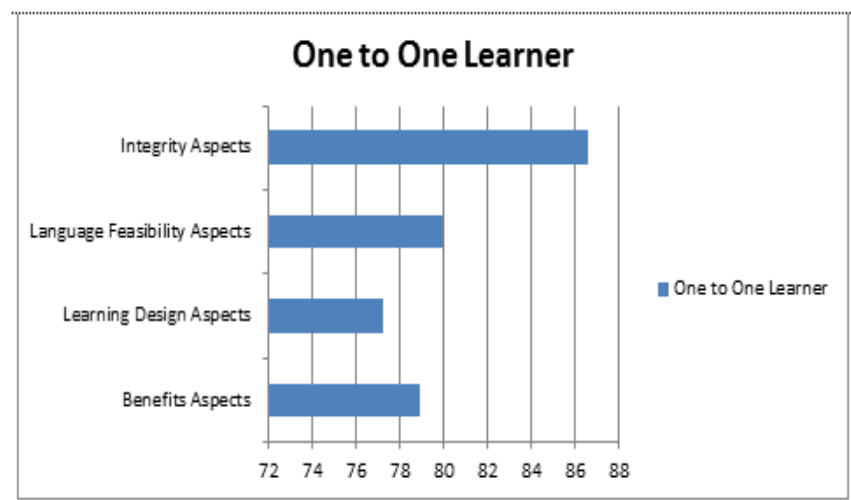

Graph 5. Individual Trial Results (One to One Learner)

Development of learning materials for Fish Stock Estimation Techniques that have been tested is quite effective in their application. This can be seen from the achievement of an average of 3 students who validated. Each of them reached an average of $4.03(80.50 \%), 3.90(78 \%)$ and $3.98(79.50 \%)$. This value illustrates that the development of the Fish Stock Estimation Learning model is in the effective category applied for students with high, medium and low abilities.

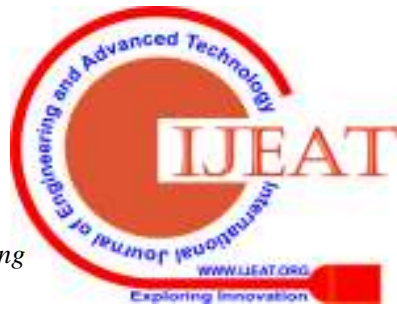




\section{Test small groups}

Formative evaluation activities for small group or small group trials were carried out involving 15 (fifteen) students, consisting of five high-ability people, five middle-capable people and five low-ability people. The purpose of this small group trial was to identify shortcomings of institutional activities after being revised based on individual evaluations. The expected input is not only about learning materials but also instructional processes.

The results of formative evaluations for small group individuals, overall students gave very good grades, namely with an average value of $85.33 \%$, there were three parts obtained from the results of this smallgroup questionnaire namely learning objectives, descriptions of learning materials, illustrations and menus. Of the three got a good rating. Subject responses to small group trials can be seen in Graph 6:

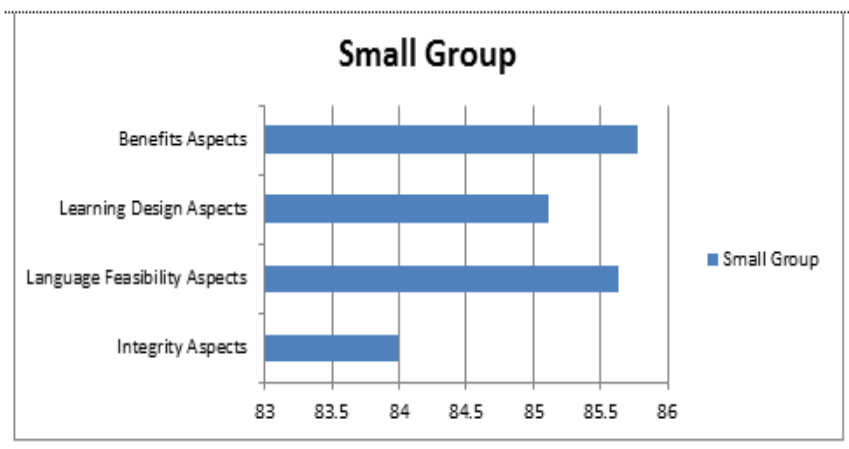

Graph 6. Small Group Test

Graph 6. Responses to Small Group Trial Subjects Overall this small group trial achieved an average value of 4.27 or $85.33 \%$ with a very good category. This shows that the proposed learning design is very feasible to use. The effectiveness of this learning design is illustrated by the results of the achievements of each student who participated in a small group trial. The results of the average achievement of 15 students who participated in this trial ranged from 4.00 to 4.80. The final conclusion of this small group trial is that the design of learning is very feasible and can be used for each level of competency of different students.

\section{Field Trials}

Based on input, suggestions, criticism and expert validation involving (learning design experts, media experts, and material experts), individual evaluations, and small group evaluations, the next step is to strengthen the final product by conducting field trials or field trials involving 30 student. The data collected in the field trial consisted of student responses to the use of learning materials. Emphasis on the trial at this stage, the design of learning materials for the Fish Stock Estimation Course from learning materials using the results of improvements from small group trials. In the process of conducting field trials students are given printed learning materials. Then students observe, understand, and learn the overall learning material. After students learn the learning materials, researchers ask for their responses to the quality of the products that researchers have developed in the form of printed books. The conclusion of this field trial as a whole is illustrated by the average achievement of 4.44 or $88.88 \%$ which is in the very good category. can be used in everyday life.
Learning Materials Effectiveness Test Test the effectiveness of learning materials for Fish Stock Estimation Techniques conducted by the assessment of learning outcomes obtained through pre-test and post-test, pre-test (initial ability test) in this case the subject score on the teaching material to be taught while post-test is the subject score of the teaching material that has been taught. The pre-test is given before the learning begins, while the post-test is given after the field test is completed. The submission of these tests closed the entire series of trials for several meetings and learning was completed. The procedures carried out in the implementation of the effectiveness test of learning material products are: 1) The developer prepares assessment instruments used for the pre-test and post-test. 2) At the initial meeting, the developer explains the purpose of the pre-test, then provides a pre-test sheet and students are asked to do it for 100 minutes.

3) After the pre-test, the developer provides learning materials. 4) Students are asked to study the subject for 3 weeks. Next the developer and students agree on the next meeting to hold a post-test. 5) In accordance with the agreement of the time on a predetermined day a post-test is held. Time given to students to do a post-test for 100 minutes. After the learning outcomes data obtained from the pre-test and post-test were analyzed using statistical tests in this case t-test was used. The value of the pre-test and post-test obtained by students can be seen in the appendix. The value data is then analyzed using Microsoft Office Excel 2016 which produces information as shown below:

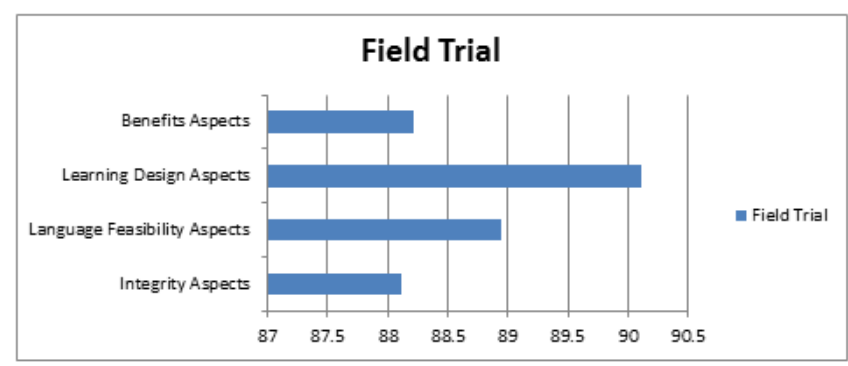

Graph 7. Field Trial Test

The data above shows that the mean difference between the pre-test and post-test scores is -24.79 . While the t-test that tests $\mathrm{H}_{\mathrm{o}}$ : $\mu$ pre-test $=\mu \mathrm{p}$-test gives a value of $\mathrm{t}=-33.58$ with 32 degrees of freedom. While the $\mathrm{p}$-value for the two-tailed (2-tailed) test is 0,000 which is smaller than $\alpha=0.05$. This data proves that the statistical hypothesis $\mathrm{H}_{0}$ : $\mu$ pre-test $=$ $\mu$ post-test is rejected. The conclusion that can be drawn is that the mean score of the pre-test and post-test is not significantly different. The data above also shows the correlation of these two variables at $\mathrm{r}=0.724$ and hypothesis test data to determine the significance of the correlation $\mathrm{p}$-value $=0.001$. In this case $p$-value $=0.001$ is smaller than $\alpha=0.05$, so the Pearson correlation is significant. Based on the above data analysis it can be concluded that the mean score of the pre-test and post-test is different, and the difference is significant (meaningful). This indicates that the Fish Stock Estimation Technique learning model used is effective because it significantly increases learning outcomes.

Published By: 


\section{DISCUSSION}

Lectures conducted can run effectively, efficiently and attractively and must be initiated through a systematic and systemic learning design process. For that we need a quality lecture design that can be guided by lecturers and students in conducting lectures. In other words the quality and success of lectures in principle depends on the quality of the design of the lecture itself. Therefore it is truly naive if lectures are carried out without a clear design or even very irony of lectures carried out without any design at all or flowing as is.

"Learning is an enduring change in behavior, or in the capacity to behave in a given fashion, which result from practice or other forms of experience" (Schunk, 2012). Learning is defined as a deliberate effort by educators to support student learning activities (Kusumandari \& Istyarini, 2015). "Learning is change in human disposition or capability that persits over a period of time and is not simply ascribable to processes of growth" (Gagne, 2005). Learning is achieved through frequent responding and immediate reinforcement of appropriate behaviors" (Shambaugh \& Magliaro, 2006). "Learning is a multifaceted process that individuals typically take for granted until they experience difficulty with a complex task" (Gredler, 2009:2). Learning means: (a) activities, and (b) experience. Both teaching and instruction influence learning through various activities and experiences. Hence, the learning and teaching mean the modification of pupils' behaviour through activities and experiences (Sharma, 2002). Learning design is needed as a solution in overcoming learning problems because it contains a series of activities both carried out by lecturers and students so that learning is directed towards achieving the expected learning goals. "Intructional Design is an iterative process of planning performance objectives, selecting instructional strategies, choosing media and selecting or creating material, and evaluations" (Branch, 2009). A series of activities in the design include various components such as students, material, learning methods / strategies, media, and evaluation. For that reason, the right method is to understand the theory related to the design of learning and then make the design appropriately. In this case the development of the Fish Stock Estimation Engineering learning material departs from the needs analysis carried out.

The results of the needs analysis were carried out using interview instruments and documentation, the results of which included: Water Resources Management Technology study program students who participated in the Fish Stock Estimation Engineering stated that the book used in the lecture was a textbook with an English introduction, the size was relatively thick so cannot be taken to the field while practicing, the contents of the book are ineffective and do not provide alternative examples. Students want learning materials that are easy to bring to the field when practicing, are not dependent on the internet and are effectively used with enrichment of material in it that can be accessed quickly with the technology they have.

Based on the analysis of these needs, it is important to develop learning materials that can be used in lectures. In this case the development of the learning materials developed was labeled namely the development of a learning model for the Fish Stock Estimation Technique.

Learning materials for fish stock estimation techniques are intended for face-to-face lecture activities. Where in face-to-face lectures, lecturers act as presenters of lecture material and students act as learners who learn from lecturers and from learning materials developed. Because this learning material product is intended for face-to-face lecturing activities, in this case it needs to be examined in an explanation (Suparman, 2012: 287) as follows: (1) learning materials in the form of compilation of available learning resources and relevant learning strategies are arranged; (2) learning outcomes assessment materials that are suitable with the learning objectives; (3) teaching guidelines on how to use compilation materials; and (4) students' guidance on how to learn and participate in learning activities under the leadership of the teacher.

Learning materials include all forms of learning such as instructions for instructors, lists of reading students, presentations with power points, case studies, videos, podcasts, computer-based multimedia, and web pages for distance education (Dick et al., 2009: 7). Learning materials contain material, content or content both written, mediated, or facilitated by the instructor, so students will use it to achieve learning goals, including materials for general purpose and special purposes and materials for improving memory and transfer (Dick et al., 2009: 230). The same thing was explained by Yaumi (2013), that learning materials are a set of materials arranged systematically for learning needs sourced from printed materials, visual aids, audio, video, multimedia and animation, as well as computers and networks.

\section{CONCLUSION}

Based on the formulation of the problem, the results of the study and in the research on the development of the Fish Stock Estimation Technique learning model, a number of conclusions can be drawn as follows:

1. Development of a learning model for Fish Stock Estimation Technique is an effort to meet the needs of improving the quality of learning in Fish Stock Engineering in the Technology Study Program for Aquatic Resources Management at the Fisheries High School.

2. The development of the Fish Stock Estimation Engineering learning model facilitates students in participating in the implementation of learning using physical models in the form of printed learning materials so as to achieve optimal results.

3. The procedure for developing the Technical Learning Model for Fish Stock Estimation has 4 steps in sequence, namely: preliminary research, planning and model development, followed by validation, evaluation, and model revision, ending with the implementation of the model.

4. In the field trial, the value obtained from the results of the post-test is higher than the value of the Pre-test, the average value of the results of the pre-test 62 and the post-test average value of 86.79 , so there is an increase of 24,79 points, the rate of increase is very significant, meaning that this figure shows that the model developed can improve student learning achievement in the Study

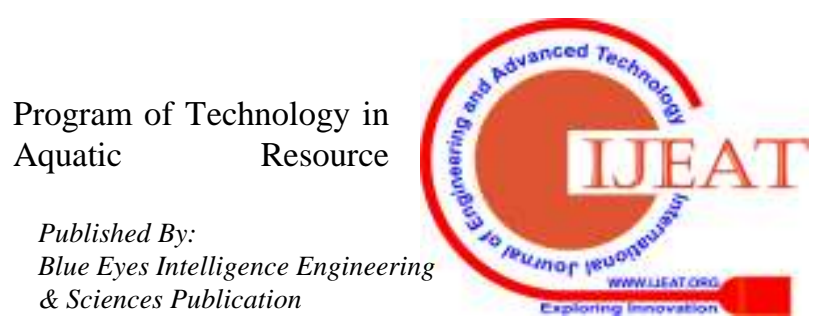


Management. While the average percentage value obtained from field trials is $88.88 \%$, this number is higher than the learning objectives specified in the specific instructional objectives of $80 \%$. So that the model developed can be categorized as effectively used in the learning process in the Technology Study Program of Fisheries High School Jakarta Water Resources Management.

\section{ACKNOWLEDGMENT}

Thanks God Almighty created, which has provided the ability to research this can be resolved amicably.

\section{REFERENCES}

1. Branch, R. M. (2009). Intructional Design: The ADDIE Approach. New York: Springer.

2. Dick, W., Carey, L., \& Carey, J. O. (2009). The Systematic Design of Instruction, Seventh Edition (Seventh Ed). New Jersey Colombus: Ohio: Pearson.

3. Gagne, M. R. (2005). The Condition of Learning and Teori of Instruction. New York: Holt Rinehart and Winston Inc.

4. Gall, M., Gall, J. P., \& Borg, W. R. (2007). Educational Research An Introduction Eight Edition (Eight Edit). Boston New York San Francisco: Pearson Allyn And Bacon.

5. Gay, L. R., Mills, G. E., \& Airasian, P. W. (2009). Educational and Applications, 9th Edition (9th Edition). New Jersey: Pearson Education Inc

6. Gaspersz. (2002). Total Quality Management. Jakarta: PT Gramedia Pustaka Utama.

7. Gredler, M. E. B. (2009). Learning and Instruction: Theory into Practice. New Jersey: Pearson.

8. Kusumandari, Rafika Bayu \& Istyarini, Character Education Development Model-based E-Learning and Multiple Intelegency in Childhood in Central Java, Global Journal of Computer Science and Technology: H Information \& Technology Volume 15 Issue 3 Version 1.0 Year 2015

9. Nikijuluw, V. P. H., Poeloe, J., Dahlan, M. N., \& Purba, C. B. (2007). Alternative System for Marine and Fisheries Resources Management. Jakarta: Pusat Riset Perikanan Tangkap, Kementrian Kelautan dan Perikanan

10. Piskurich, G. M. (2000). Rapid Instructional Design: Learning ID Fast and Right. San Francisco: Jossey-Bass/Pfeifer.

11. Richey, R.C., \& Nelson, W. A. (2000). Development Research: Handbook of Research for Educational Communication and Technology, ed. D.H. Jonnassen. New York: Maximillan Library

12. Schunk, D. H. (2012). Learning theories: An educational perspective. (6th. Ed.). Boston, MA: Pearson.

13. Schwier, R. A., \& Misanchuk, F. R. (n.d.). Interactive Multimedia Instruction. New Jersey: Educational Technology Publications.

14. Shambaugh, N., \& Magliaro, S. G. (2006). Instructional Design A Systematic Approach for Reflective Practice. Boston: Pearson.

15. Sharma, Y. K. (2002). Fundamental Aspects of Educational Technology. New Delhi: Kanishka Publishers, Distributors.

16. Suparman, M. A. (2012). Modern Instructional Design: Guide to Educational Teachers \& Innovators. Jakarta: Erlangga.

17. Yaumi, M. (2013). Principles of Learning Design. Jakarta: Kencana Prenada Media Group

\section{AUTHORS PROFILE}

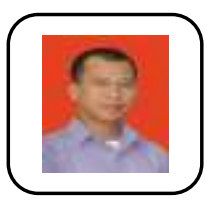

Heri Triyono. Was born on October 20, 1972. Lecturer at Sekolah Tinggi Perikanan Jakarta. He have many experience and interested on research: Biological Aspects and Aspects of Catching Cakalang (Katsuwonus pelamis) that Landed at the Cilacap Ocean Port (PPSC), Central Java (2009), Reproductive aspects and Oskar fisheries (Amphilophus citrinellus) that are caught with Gill Nets on the Jatiluhur Reservoir General Waters, Purwakarta, West Java (2010), Analysis of the Ability of Milkfish and Tilapia in Utilizing the Plankton Abundance in Ir reservoir H. Djuanda, Jatiluhur, Purwakarta, West Java (2010), Biological and Fisheries Aspects of Fly Deles (Decapterus macrosoma) Landed At the Fishery Port of Bajomulyo Juwana Beach, Pati Regency - Central Java (2011), Formosa Coral Acropora Growth on Biorock Substrate in Gili Trawangan, North Lombok (2011), Biological Aspects and Catching Aspects of Yellow Tails (Caseio cuning) Landed At the Fishery Port of Karimunjawa Beach, Kab. Jepara, Central Java (2012), Community Structure of Seagrass and Associated Biota and Its Conservation Efforts on the Island Mataha, Berau Regency, East Kalimantan (2012), Biota Communities Associated at Reef Ball in Benete Bay, West Sumbawa (2013) Biological and Fishery Aspects of Blue Fly Fish (Decapterus macarellus) Landed On Kendari Ocean Fisheries Port (PPS), Southeast Sulawesi (2013), Biological and Fishery Aspects of Julung-Julung Fish (Hemirhamphus far) Landed On Tanjung Luar Fish Landing Base (PPI), Lombok, NTT (2014), Relation of the Abundance of Target Fish to the Condition of Coral Reefs in the Waters Kapoposang Island, South Sulawesi (2014), Study of Biological Aspects and Fisheries Aspects of Male Mackerel (Rastrelliger kanagurta) Landed at Morodemak Beach Fisheries Port (PPP), Central Java (2015), Biology and Fisheries Aspects of Kuniran caught by Dogol and landed at VAT Brondong, East Java (2015), Biological Aspects and Fisheries Aspects of Male Mackerel landed in PPP

Muarademak-Central Java (2016), Study of Biological Aspects and Fisheries Aspects of Lanjaman Cucut and landed in the Port Brondong-Eas Java Nusantara Fisheries (PPN) (2016), Study of Biological Aspects of Fisheries and Utilization of Meow Sharks in Bugis Village, District Sape, Bima Regency, West Nusa Tenggara (2017), Study of Grouper Management with an Ecosystem Approach on the Waters of Bintan Island, Riau Province (2017), Productivity and Susceptibility Analysis of Indonesia Spiny Lobster Fishery (2018), Current Indonesian Ornamental Fish Status: Diversity, Conservation, Trade and management (2018).

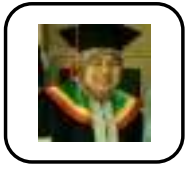

Diana Nomida Munsir, Professor in Educational Technology, Postgraduate Program, Universitas Negeri Jakarta. Permanent daily lecturers teach and guide the Thesis and Disertation of postgraduate student in the Educational Technology Departement, Universitas Negeri Jakarta. Some of the studies carried out include: Improving Mathematical Learninf Results with Student Blended Learning and Achievement Motivation, The effect of grant block programs on life acquisition to English learning results. Relation between independent learning and echievement motivation with Islamic Religion Education Learning Outcomes in SMP Terbuka. Effectiveness of Learning Strategy and Learning Style on Learning Outcome. Relation between Module Readability and Motivation Achieving The Learning Outcomes of Accounting Subjects in SMA Terbuka. Learning based Multiple Intelegence.

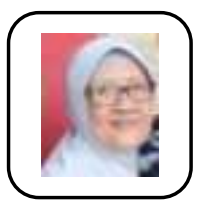

Suriani, Professor in Educational Technology, Postgraduate Program, Universitas Negeri Jakarta. Permanent daily lecturers teach and guide the Thesis and Disertation of postgraduate student in the Educational Technology Departement, Universitas Negeri Jakarta Some of the studies carried out include: Improving Mathematical Learninf Results with Student Blended Learning and Achievement Motivation, The effect of grant block programs on life acquisition to English learning results. Relation between independent learning and echievement motivation with Islamic Religion Education Learning Outcomes in SMP Terbuka. Effectiveness of Learning Strategy and Learning Style on Learning Outcome. Relation between Module Readability and Motivation Achieving The Learning Outcomes of Accounting Subjects in SMA Terbuka. Learning based Multiple Intelegence 